\title{
Study on Yield and Corm Regeneration of Saffron through Different Planting Geometry Patterns
}

\author{
G. Ali, M.H. Khan*, F.A. Nehvi, S.A. Dar, S.A. Nagoo, S. Naseer, \\ B.A. Alie and Mir G. Hassan \\ Saffron Research Station, SKUAST-Kashmir, Pampore, India \\ *Corresponding author
}

\begin{tabular}{|l|}
\hline Ke y w o r d s \\
Planting density, \\
$\begin{array}{l}\text { Spacing, Yield, } \\
\text { Corm regeneration, } \\
\text { Saffron }\end{array}$ \\
\hline Article Info \\
\hline $\begin{array}{l}\text { Accepted: } \\
\text { 06 July } 2018 \\
\text { Available Online: } \\
\text { 10 August } 2018\end{array}$ \\
\hline
\end{tabular}

\section{A B S T R A C T}

A field experiment was conducted in order to examine the effect of different plant geometries and spacing between the pits on corm regeneration and yield. The experiment was laid out in a randomized block design with three replications at the Research Farm of Saffron Research Station, SKUAST-Kashmir, Pampore for 3 years viz., 2012-13, 2013-14 2014-15. The treatments consisted of three planting methods viz., 15 corms per pit $\left(\mathrm{P}_{1}\right), 10$ corms per pit $\left(\mathrm{P}_{2}\right)$ and 5 corms per pit $\left(\mathrm{P}_{3}\right)$ and two spacing from pit to pit viz., $30 \times 20 \mathrm{cms}$ $\left(\mathrm{S}_{1}\right)$ and $25 \times 10 \mathrm{cms}\left(\mathrm{S}_{2}\right)$. The statistical data and details from the second and third year of the experiment were evaluated and analyzed. Analysis of variance showed significant variation among all the treatments. The highest number of daughter corms/plot was obtained from the highest density $(15 \mathrm{corms} / \mathrm{pit})$ and wider spacing $(30 \times 20 \mathrm{cms})$. It was also noticed that highest number of total corms/row weighting $>10 \mathrm{~g}, 5-8 \mathrm{~g},<5$ gram were recorded under the same treatment $\left(\mathrm{P}_{1}-15 \mathrm{corms} / \mathrm{pit}\right)$ as $9.00,7.59$ and $49.02 \mathrm{corms}$, respectively. Further, the total corm weigh /pit was significantly highest $(158.55 \mathrm{gms})$ in $\mathrm{P}_{1}$ (15 corms per pit) treatment as compared to other treatments. With regard to the floral traits viz., no. of flower/plant, flower fresh weight (gm), flower dry weight (gm), stigma fresh weight $(\mathrm{gm})$ and stigma dry weight $(\mathrm{mg})$, the treatment $\mathrm{P}_{1}(15$ corms per pit) and spacing $S_{1}(30 \times 20 \mathrm{cms})$ produced significantly highest mean values for these traits. Significantly highest saffron yield $\left(5.80 \mathrm{~kg} \mathrm{ha}^{-1}\right)$ was recorded in the treatment $\mathrm{P}_{1}(15$ corms per pit), while the lowest yield $\left(3.89 \mathrm{~kg} \mathrm{ha}^{-1}\right)$ was recorded in treatment $\mathrm{P}_{3}(5 \mathrm{corms}$ per pit), similarly the spacing treatment $S_{1}(30 \times 20 \mathrm{cms})$ produced the highest saffron yield $\left(5.09 \mathrm{~kg} \mathrm{ha}^{-1}\right)$ as compared to $\mathrm{S}_{2}(25 \times 10 \mathrm{cms})$ treatment $\left(4.58 \mathrm{~kg} \mathrm{ha}^{-1}\right)$.

\section{Introduction}

Saffron (Crocus sativus L.) a perennial herb belongs to Iris family Iridaceae is the most expensive spice in the world known for its aroma and colour and used for flavouring and colouring in medicinal and pharmaceutical industries. It is derived from the dry stigmas of the plant popularly known as the "Golden Condiment". The colour, flavour and aroma of saffron are mainly due to crocin, picrocrocin and safranal, respectively. Main constituents for intense colour of saffron are lipophilic and hydrophilic carotenoids. These are $\beta$-crocetin, $\gamma$-crocetin, $\alpha$-carotene, $\beta$-carotene, lycopene, zeaxanthin. A glycosidic form of crocetin 
digentiobioside (crocin 1) is most abundant by weight and soluble in water. In saffron pigments, crocetin portion is common with different sugar moieties which are gentiobiose, D-glucose, and neapolitanose- a trisaccharide. The bitter taste of saffron is due to monoterpene aldehyde picrocrocin $\left(\mathrm{C}_{16} \mathrm{H}_{26} \mathrm{O}_{7}\right)$. For aroma, main constituent responsible is safranal and its hydroxyl derivative formed by hydrolysis of picrocrocin during drying. Besides, many other trace compounds also contribute to aroma of saffron. Due to very high crocin content and rich aroma, the Kashmiri saffron is famous worldwide and commands a premium price over the saffron available from Spain or Iran. It is principally used as food additive in dairy products, vegetarian and culinary dishes and gives pleasant flavour, distinctive colour and delicate aroma and is an irreplaceable spice. Besides, it is used in colouring industry, paintings and staining of histological sections. It is also used in cosmetic preparations due to antioxidant and probably anti-aging activity. Crocin, picrocrocin, safranal and crocetin also contribute to health-promoting properties. In small doses it is used as sedative, expectorant, stimulant, aphrodisiac and antispasmodic. Picrocrocin has a sedative effect on spasms.

Saffron is a legendry crop of Jammu and Kashmir produced on well drained karewa soils of Kashmir and Kishtwar where ideal climatic conditions are available for good growth and flower production. It grows at an elevation of 1500-2000 m amsl. Photoperiod and temperature exerts a profound influence on the flowering of saffron. An optimum period of 11 hours illumination and moderate temperature of about $18-20^{\circ} \mathrm{C}$ during flowering is found optimum. Unusually low temperature coupled with high humidity during flowering season affects flowering. Spring rains boost production of new corms. Slightly acidic to neutral, gravelly, loamy, sandy soils are suitable for saffron cultivation.
The cultivated saffron being a triploid, fails to produce seeds upon selfing or crossing. Because of this sterility, work on breeding saffron for better quality and higher yield is very difficult (Mathew, 1982). There is also a very rare genetic variation for increased number of stigmas, anthers and perianth parts in saffron (Estilai, 1978). Therefore, there are less possibilities for improving the produce quantitatively and qualitatively through conventional methods of selection and breeding. Thus leaving a room to improve yield and quality by agronomic manipulations for which a thorough knowledge of the growth stages and developmental behaviour of the saffron is considered a pre-requisite. Among other agronomic factors responsible for low yield of saffron under valley, planting geometry and spacing has a great role to play in increasing saffron yield and quality. Planting technique and spacing not only ensures proper adjustment and optimum plant population in the field but also enables the plants to utilize the land and other input resources more efficiently towards growth and development. Suitable planting density in saffron will increase the period of exploitation (Abrishami, 1997). Behdad (2001) studied plant density in both single and double corms and reported that single corm cultivation had lower performance. Behnia and Mokhtarian (2010) stated that 10 corms with 30 (cm) spacing between rows had maximum yield. The planting of saffron at higher densities led to increase in the yield during first three years of planting (Kochaki et al., 2012).Spacing usually has a large effect on crop yield, however, so far little research on saffron spacing has been reported internationally. One-year study reported that the most-dense planting gave the highest stigma yield per unit area as expected (Bullitta et al., 1996). However, planting at an intermediate density (inter-row spacing of $20 \mathrm{~cm}$ with intra-row spacing of $10 \mathrm{~cm}$ ) was recommended by McGimpsey (1993). The objective of this 
study was to examine the effect of different plant geometries and spacing between the pits on corm regeneration and yield.

\section{Materials and Methods}

A field experiment was laid out in a randomized block design with three replications at the Research Farm of Saffron Research Station, SKUAST-Kashmir, Pampore for 3 years viz., 2012-13, 2013-14 2014-15. The treatments consisted of 3 planting methods viz., 15 corms/pit $\left(\mathrm{P}_{1}\right), 10$ corms/pit $\left(\mathrm{P}_{2}\right)$ and 5 corms/pit $\left(\mathrm{P}_{3}\right)$ and 2spacing's (pit to pit) viz., $30 \times 20 \mathrm{cms}\left(\mathrm{S}_{1}\right)$ and $25 \times 10 \mathrm{cms}\left(\mathrm{S}_{2}\right)$. Recommended package of practices were followed for raising a healthy crop. Ten plants were randomly selected in each plot in each replication for obtaining the data on 5 corm traits viz., daughter corm/plot, total corm weight, number of corms (>10 g, 5$8 \mathrm{~g}$ and $<5 \mathrm{~g}$ ) and 6 floral and yield traits(for 100 flowers) viz., no. of flower/plant, flower fresh weight $(\mathrm{gm})$, flower dry weight $(\mathrm{gm})$, stigma fresh weight (gm), stigma dry weight $(\mathrm{mg})$ and yield $(\mathrm{kg} / \mathrm{ha})$. Flowers were picked each day or each alternate day. The red part of the stigmas were cut by fingernails from the flower and dried in an oven at $50^{\circ} \mathrm{C}$ for 3 hours to a constant weight. Flower numbers were recorded separately for each plot. Weight of red stigmas was recorded on 100 flower basis. In order to monitor corm multiplication, 10 corm clusters (each derived from one planted corm) were randomly dug up. The diameter and weight of the largest corm were measured, and the number of smaller corms was also recorded. Corms were dug up from one-third of each plot. The diameter and weight of the largest corm from 30 random samples were measured, and the number and total weight of smaller corms were also recorded. The corms were sorted according to weight and re-planted. The data obtained in respect of various observations were statistically analyzed by the method described by Cochran and Cox (1963). The significance of " $F$ " and " $t$ " was tested at $5 \%$ level of significance.

\section{Results and Discussion}

\section{Floral traits and saffron yield}

Analysis of variance for individual as well as interaction effects showed significant variation among all the treatments except flower dry weight, stigma fresh weight and stigma dry weight where effect were found nonsignificant (Table 1). These results are in agreement with the earlier reports of Mollafilabi et al., (2014). The perusal of data (Table 2) indicated that planting densities and spacing produced significant difference on number of flowers/plant. The treatment $\mathrm{P}_{1}(15$ corms/pit) produces significantly highest number of flowers (1.97) while least number of flowers (1.64) were produced by treatment $\mathrm{P}_{3}$ (5 corms/pit). Similarly, spacing of $\mathrm{S}_{1}$ $(30 \times 20 \mathrm{cms})$ produced significantly higher number of flowers (1.95) as compared to $S_{2}$ (25x10 cms) spacing (1.60). Previous studies have shown that in the second experimental year, absorbing foods through roots and photosynthesis by leaves resulted in producing corms with more weights compare to the first year (Badiyala and Saroch, 1997), which had a positive effect on the number of saffron leaves and produced more assimilates (Pandy and Srivastava, 2000). On the other hand, larger corms increased flowering capacity and yield during next years through producing more daughter corms (Sadeghi, 1993). With regard to flower fresh weight, planting density showed significant increase from $\mathrm{P}_{1}$ (15 corms/pit) to $\mathrm{P}_{3}$ (5 corms/pit) and same trend was also noticed with regard to the spacing with significantly highest flower fresh weight in $\mathrm{S}_{1}(30 \times 20 \mathrm{cms})$ and lowest in $\mathrm{S}_{2}(25 \times 10$ $\mathrm{cms})$. The results also revealed that planting density of $\mathrm{P}_{1} \quad(15$ corms/pit $)$ exhibited significantly highest flower dry weight (6.14 
g) which was followed by $\mathrm{P}_{2}$ (10 corms/pit) $(6.06 \mathrm{~g})$ and $\mathrm{P}_{3}$ (5 corms/pit) (5.94 g), however, spacing didn't produced any significant effect on flower dry weight. Similar trend was also noticed with regard to the stigma fresh and dry weight with significantly highest stigma fresh and dry weight in planting density of $\mathrm{P}_{1}(15$ corms/pit) and lowest in $\mathrm{P}_{3}$ (5 corms/pit). These results are in agreement with the earlier reports of Nazarian et al., (2016) who reported that highest number of flowers, flower fresh weight and (stigma + style) dry weight were obtained in high density plantation, while lowest values of these traits were obtained in low density plantation. Mohammadi et al., (2013) observed that different planting densities have a significant impact on length of stigma. They mentioned that the length of stigma was reduced by increasing plant density due to competition among saffron plants. Gresta et al., (2009) and Rostami and Mohammadi (2013) reported that there is a negative relationship between corm density and dry weight of stigma that is inconsistent with the present study. Juan et al., (2009) observed that dry weight of stigma was decreased by increasing corm density. Since dry weight of stigma has effect on total yield, they believed that optimal density of corms depends on the yield comparison unit in such a way that if yield is expressed in terms of corm weight, less corm density will be more appropriate and if it is expressed based on area planted, more corm density will be better. Spacing treatments didn't showed any significant effect on the stigma fresh and dry weight, however, highest mean values for these traits were noticed in spacing treatment $\mathrm{S}_{1}(30 \times 20 \mathrm{cms})$. The present findings are in contrast with the earlier reports of Andabjadid et al., (2015) who reported that length of stigma, dry weight of flower, fresh and dry weight of stigma were significantly affected by lesser spacing within rows. Yield of crop is the most important criterion for comparing and judging the efficiency of different treatments. The data regarding the effect of different treatments on saffron yield are presented in Table 2. Planting densities showed significant effect on saffron yield. The planting density of $\mathrm{P}_{1}$ (15 corms/pit) recorded significantly higher yield $\left(5.80 \mathrm{~kg} \mathrm{ha}^{-1}\right)$ as compared to (4.89 $\left.\mathrm{ha}^{-1}\right)$ and $\left(3.89 \mathrm{ha}^{-1}\right)$ at planting densities of $\mathrm{P}_{2}$ (10 corms/pit) and $\mathrm{P}_{3}$ (5 corms/pit), respectively. Similarly, spacing treatment $S_{1}(30 \times 20 \mathrm{cms})$ showed significantly higher yield $\left(5.09 \mathrm{~kg} \mathrm{ha}^{-1}\right)$ as compared to 4.58 $\mathrm{kg} \mathrm{ha}^{-1}$ in spacing treatment of $S_{2}(25 \times 10 \mathrm{cms})$. It seems that increasing corms density and reducing corms distances between and within rows, cause enhancement in yield. Results of the present study are in accordance with the earlier reports of Behnia (2008) and Kochaki et al., (2012) who concluded that yield increased significantly by increasing plant density. Galavand and Abdollahian-Noghani (1994) reported that planting pattern of corms in $30(\mathrm{~cm})$ distance between lines and $10(\mathrm{~cm})$ space within rows had more performance. Alavi-Shahri et al., (1994) stated that by increasing corm density, saffron yield increased. They believed that more spacing between rows and within rows were appropriate in terms of performance increase. Yau and Nimah (2004) indicated that more planting distances is superior than lesser distances. Results of the present study is in conflict with results of Mohammad-Abadi et al., (2007) who reported planting density had no significant effect on the saffron yield. Probably interaction of planting density with numerous factors such as planting depth and method can contain different effects and therefore different results can be attributed to these cases. High planting density increases the yield in the unit area and limits the exploitation period of saffron. Researchers concluded that the highest yield and the exploitation period of saffron can be obtained in the highest planting density (Naderi Dar BaghShahi et al., 2008). 
Table.1 Analysis of variance of corm traits of saffron

\begin{tabular}{|c|c|c|c|c|c|c|}
\hline \multirow[t]{2}{*}{ Source } & \multirow[t]{2}{*}{ df } & \multicolumn{5}{|c|}{ Mean squares } \\
\hline & & Daughter corm/plot & Total corm weight & $>10 \mathrm{~g}$ & $5-8 \mathrm{~g}$ & $<5 \mathrm{~g}$ \\
\hline Replications & 2 & 70.45 & 362.71 & 1.68 & 1.45 & 39.17 \\
\hline Factor A & 2 & $2054.80 * *$ & $18419.23 * *$ & $18.50 * *$ & $6.50 * *$ & $1075.17 * *$ \\
\hline Factor B & 1 & $112.60 * *$ & $264.65 *$ & $12.52 * *$ & $2.00 * *$ & $98.09 * *$ \\
\hline Factor A X B & 2 & $10.49 *$ & 15.49 & $0.50 *$ & $0.50 * *$ & $9.51 *$ \\
\hline Error & 10 & 1.54 & 13.43 & 0.02 & 0.01 & 0.82 \\
\hline Total & 17 & & & & & \\
\hline
\end{tabular}

Table.2 Influence of planting density and spacing on corm attributes of saffron

\begin{tabular}{|c|c|c|c|c|c|}
\hline Treatments & Daughter corm/plot & Total corm weight & $>10 \mathrm{~g}$ & $5-8 \mathrm{~g}$ & $<5 \mathrm{~g}$ \\
\hline$P_{1}$ (15 corms/pit) & 66.52 & 158.55 & 9.00 & 7.59 & 49.02 \\
\hline $\mathbf{P}_{2}$ (10 corms/pit) & 43.02 & 110.04 & 7.00 & 6.91 & 32.51 \\
\hline$\overline{P_{3} \text { (5 corms/pit) }}$ & 30.01 & 48.02 & 5.50 & 5.50 & 22.53 \\
\hline $\mathbf{S E}(\mathbf{m}) \pm$ & 0.716 & 2.116 & 0.077 & 0.043 & 0.523 \\
\hline $\mathrm{CD}$ & 1.595 & 4.712 & 0.172 & 0.097 & 1.164 \\
\hline $\mathrm{S}_{1}(30 \times 20 \mathrm{cms})$ & 49.02 & 109.37 & 8.00 & 7.00 & 37.01 \\
\hline $\mathrm{S}_{2}(25 \times 10 \mathrm{cms})$ & 44.01 & 101.70 & 6.33 & 6.33 & 32.34 \\
\hline $\mathrm{SE}(\mathrm{m}) \pm$ & 0.585 & 1.728 & 0.063 & 0.036 & 0.427 \\
\hline CD & 1.302 & 3.848 & 0.140 & 0.079 & 0.950 \\
\hline
\end{tabular}


Table.3 Analysis of variance for floral traitsand yield (100 flowers) of saffron (100 flowers)

\begin{tabular}{|c|c|c|c|c|c|c|c|}
\hline \multirow[t]{2}{*}{ Source } & \multirow[t]{2}{*}{ df } & \multicolumn{6}{|c|}{ Mean squares } \\
\hline & & $\begin{array}{c}\text { No. of } \\
\text { flower/plant }\end{array}$ & $\begin{array}{c}\text { Flower Fresh } \\
\text { weight (gm) }\end{array}$ & $\begin{array}{l}\text { Flower dry } \\
\text { weight (gm) }\end{array}$ & $\begin{array}{c}\text { Stigma fresh } \\
\text { weight (gm) }\end{array}$ & $\begin{array}{l}\text { Stigma dry } \\
\text { weight (mg) }\end{array}$ & $\begin{array}{c}\text { Yield } \\
\text { (kg/ha) }\end{array}$ \\
\hline Replications & 2 & 0.10 & 49.82 & 1.18 & 0.05 & 11308.10 & 0.76 \\
\hline Factor A & 2 & $0.13 * *$ & $72.34 * *$ & $0.06 * *$ & $0.07 *$ & $1775.55^{*}$ & $5.44 * *$ \\
\hline Factor B & 1 & $0.60 * *$ & $4.50 *$ & 0.00 & 0.00 & 0.50 & $1.21 * *$ \\
\hline Factor A X B & 2 & $0.64 * *$ & $95.68 * *$ & $0.11 * *$ & $0.14^{*}$ & $4479.25^{*}$ & $0.03 *$ \\
\hline Error & 10 & 0.00 & 0.12 & 0.00 & 0.01 & 247.03 & 0.00 \\
\hline Total & 17 & & & & & & \\
\hline
\end{tabular}

Table.4 Influence of planting density and spacing on floral traits and yield of saffron (100 flowers)

\begin{tabular}{|c|c|c|c|c|c|c|}
\hline Treatments & $\begin{array}{c}\text { No. of } \\
\text { flower/plant }\end{array}$ & $\begin{array}{c}\text { Flower Fresh } \\
\text { weight (gm) }\end{array}$ & $\begin{array}{l}\text { Flower dry } \\
\text { weight (gm) }\end{array}$ & $\begin{array}{l}\text { Stigma fresh } \\
\text { weight (gm) }\end{array}$ & $\begin{array}{l}\text { Stigma dry } \\
\text { weight (mg) }\end{array}$ & $\begin{array}{c}\text { Yield } \\
\text { (kg/ha) }\end{array}$ \\
\hline$P_{1}$ (15 corms/pit) & 1.95 & 42.87 & 6.14 & 3.48 & 698.23 & 5.80 \\
\hline$P_{2}(10$ corms/pit) & 1.76 & 39.26 & 6.06 & 3.30 & 676.73 & 4.82 \\
\hline $\mathbf{P}_{3}$ (5 corms/pit) & 1.64 & 35.21 & 5.94 & 3.22 & 664.22 & 3.89 \\
\hline $\mathbf{S E}(\mathbf{m}) \pm$ & 0.016 & 0.203 & 0.007 & 0.042 & 9.074 & 0.039 \\
\hline $\mathrm{CD}$ & 0.035 & 0.452 & 0.016 & 0.094 & 20.208 & 0.087 \\
\hline $\mathrm{S}_{1}(30 \times 20 \mathrm{cms})$ & 1.97 & 40.61 & 6.08 & 3.41 & 681.89 & 5.09 \\
\hline $\mathrm{S}_{2}(25 \times 10 \mathrm{cms})$ & 1.60 & 37.42 & 6.01 & 3.26 & 676.56 & 4.58 \\
\hline $\mathrm{SE}(\mathrm{m}) \pm$ & 0.013 & 0.166 & 0.010 & 0.045 & 7.409 & 0.055 \\
\hline $\mathrm{CD}$ & 0.028 & 0.399 & NS & NS & NS & 0.071 \\
\hline
\end{tabular}




\section{Corm and corm attributes}

Analysis of variance for planting density, spacing and their interaction showed significant effects on all the traits related to corm (Table 3). The data on daughter corms/plot as influenced by planting densities and spacings are presented in Table 4.

Significantly the highest daughter corms (66.52) were recorded in planting density $\mathrm{P}_{1}$ (15 corms/pit) and the lowest (30.01) was noticed in planting density $\mathrm{P}_{3}$ (5 corms/pit). These results are in line with the earlier reports of Behnia and Mokhtari (2009) who reported that maximum density of saffron corms produced the highest number of corms per row.

The results of Torabi and Sadeghi (1994) showed that by dwindling maternal corms, daughter corm roots don't have any role in absorbing food and to make larger daughter corms, it depends on the food transferring from mother to the daughter and also photosynthesis process.

It seems that in the second year, the cell division in corms and growth of leaves occur sooner which provides greater use of environmental conditions and finally results in more photosynthetic material to be transferred into root and producing corms with more weight at the end of the growth year (Moolina et al., 2005).

In another 5-year research, Alavi-Shahri et al., (1994) stated that increasing plant density significantly increases saffron yield and they recommended the higher density with close spacing for achieving higher yields. Significantly highest daughter corms/plot (49.02) were recorded in spacing $S_{1}(30 \times 20$ $\mathrm{cms})$ as compared to 44.01 daughter corms/plot in $\mathrm{S}_{2}(25 \times 10 \mathrm{cms})$. The data pertaining to total corm weight (Table 4) revealed that planting density $\mathrm{P}_{1} \quad$ (15 corms/pit) produced significantly high total corm weight (158.55 g) while the lowest corm weight was recorded in treatment $\mathrm{P}_{3}$ (5 corms/pit) (48.02). These results are in accordance with the earlier reports of Juan $e t$ al., (2003) who reported that planting at high density $\mathrm{m}^{-2}$ gave the highest corm yield. Pandey and Srivastava's study (2000) showed that increase in the weight/density of corm has a positive effect on number of daughter corm formation and saffron yield during the next years.

Spacing $\mathrm{S}_{1}(30 \times 20 \mathrm{cms})$ showed significantly more total corm weight $(109.37 \mathrm{~g})$ as compared to $S_{2}(25 \times 10 \mathrm{cms})(101.70 \mathrm{~g})$. It was also noticed that significantly highest number of total corms/row weighting $>10 \mathrm{~g}$, 5 $8 \mathrm{~g},<5 \mathrm{~g}$ were recorded in treatment $\mathrm{P}_{1}(15$ corms/pit) as 9.00, 7.59 and 49.02 corms, while lowest number of corms/row were recorded in treatment $\mathrm{P}_{2}(10 \mathrm{corms} / \mathrm{pit})$ as $5.50,5.50$ and 22.53 , respectively.

Similarly, spacing treatments also produced significant effects on number of corms/row. The treatment $S_{1}(30 \times 20 \mathrm{cms})$ produced significantly highest number of corms/row (8.00, 7.00 and 37.01) as against of 6.33, 6.33 and 32.34 in $S_{2}(25 \times 10 \mathrm{cms})$ treatment, respectively.

The study of Naderi-Darbaghshahi et al., (2008), showed that plant method and density showed significant effect on the number of corn per unit of area. The number of corm produced in furrow cultivation method (391.8 corms per square meter) was significantly more than the number of corms in basin method (334.1 corms per square meter). They stated that this appropriate number of corms can be attributed to the less soil density around maternal corms and better growth possibility, which can have significant effect on yield during the next years. Since daughter 
corms are formed on the maternal corms (Behnia, 1990), and their production depends on attributing additional assimilates of maternal corms, and density effects on this property through making production resource restriction, this research tried to analyze the effect of plant density on the amount of saffron corm regeneration.

In the present research different plant density and spacing's were used in order to improve corm and saffron yield and it was noticed that both these treatments showed significant effect on corm and saffron yield. Thus, the study lead to the conclusion that for realizing higher number of daughter corms and saffron yield, the corm density should be 15 corms per pit with a spacing of $30 \times 20 \mathrm{cms}$ from pit to pit. But such studies require more critical testing at various locations over a longer period before final recommendations are made.

\section{References}

Abrishami, M.H. 1997. Saffron of Iran. Toss publications, p. 320.

Alavi-Shahri, K., Mohajeri, A., and Falaki, M.A. 1994. Effect of Plant Density on Saffron Yield. Second Conference on Saffron and Pharmaceutical plant cultivation, Gonabad, Iran.

Andabjadid, S.S., Eslam, B. P., Bakhtavari, A. R. S., and Mohammadi, H. 2015. Effects of corm size and plant density on Saffron (Crocus sativus L.) yield and its components. International Journal of Agronomy and Agricultural Research, 6(3): 20-26.

Badiyala, D., and Saroch, K. 1997. Effect of seed corm size and planting geometry on saffron (Crocus sativus L.) under dry temperate conditions of Himachal Pradesh. Indian Perfumer, 41: 167-169.

Behdad, M., 2001. Survey of plant density and cultivation methods to two forms, single and double corms, in saffron. The final report of the research project, Ministry of Agriculture, Seed and plant improvement institute, 12-20.

Behnia, M., 2008. Effect of planting methods and corm density in saffron (Crocus sativus L.) yield in Damavand region. Pajouhesh and Sazandegi 79: 101-108.

Behnia, M.R., 1990. Agriculture of Saffron. Tehran University Publication, P: 260.

Behnia, M.R., and Mokhtari, M. 2009. Effect of planting methods and corm density in saffron (Crocus sativus L.). 3rd International Symposium on Saffron. Forthcoming Challenges in Cultivation, Research and Economics. 20-23 May, Korokos, Kozani, Greece.

Behnia, M.R., and Mokhtari, M. 2010. Effect of planting methods and corm density in saffron yield. Acta Horticulturae, 850: 131-136.

Bullitta, P., Milia, M., Pinna, M.E., Satta, M., and Scarpa, G.M. 1996. Sowing density and crom size: two fundamental aspects of the cultivation of saffron. Rivista Italiana EPPOS 19: 139-145.

Cochran, G.C., and Cox, M.M. 1963. Experimental Designs. Asia Publishing House, Bobmay, pp. 293-316.

Estilai, A. 1978. Variability in saffron (Crocus sativus L.). Experientia 34:725-727.

Ghalavand, A., and Abdollahian-Noghani, M. 1994. Study ecological adaption and effect of plant density and planting method on yield of native saffron bulks of Iran. Proceedings of the Second Conference of Saffron and Medical Plants Cultivation, Gonbad, Iran 33-39.

Gresta, F., Avola, G., Lombardo, G.M., Siracusa, L., and Ruberto, G. 2009. Analysis of flowering, stigmas yield and qualitative traits of saffron (Crocus sativus L.) as affected by environmental conditions. Scientia Horticultura 119: 320-324.

Juan, A.D., Lopez-Corcholes, H., Munoz, R.M., and Picornell, M.R. 2009. Yield and yield components of saffron under different cropping systems. Industrial Crops and Products30:212-219. 
Juan, J.A. de, Moya, A., Lopez, S., Botella, O., Lopez, H., and Munoz, R. 2003. Influence of the corm size and the density of planting on the yield and quality of corm produced in Crocus sativus L. Production Vegetal 99: 169-180.

Kochaki, A., Tabrizi, L., Jahani, M., and Mohammad-Abadi, A.A. 2012. Evaluation of high density of corm and three planting methods on agronomic characteristics of saffron and corms behavior. Iranian Journal of Horticultural Science 4: 391-397.

Mathew, B. 1982. London: BT Batsford ed. London; 1982. The crocus - A revision of the Genus crocus, Batsford.

McGimpsey, J. 1993. Saffron - Crocus sativus. http://www.crop.cri.nz/broadshe/echinace .htm

Mohamad-Abadi, A.A., Rezvani-Moghaddam, P., and Sabori, A. 2007. Effect of plant distance on flower yield and qualitative and quantitative characteristics of forage production of saffron (Crocus sativus L.) in Mashhad conditions. ActaHorticulturae 739: 151-153.

Molina, R.V., Valero, M., Navarro, Y., GarciaLuice, A., and Guardiola, J.L. 2005. Low temperature storage of corms extends the flowering season of saffron (Crocus sativus L.). The Journal of Horticultural Science and Biotechnology 80: 319-326.

Mollafilabi, A., Alireza Koocheki, A., Moghaddam, P. R., and Mahallati, M. N. 2014. Effect of plant density and corm weight on yield and yield components of saffron (Crocus sativus L.) under soil, hydroponic and plastic tunnel cultivation.
Journal of Saffron Agronomy and Technology, 1(2): 14-28.

Naderi-Darbaghshahi, M.R., Khaje-Bashi, S.M., Bani- Tabae, S.A., and Dehdashti, S.M. 2008. Effect of Plant method, Density and Depth on Saffron (Crocus sativus L.) Yield and operation period from farm in Isfahan Region. J Seed Plant, 24: 643657.

Nazarian, R., Sahabi, H., Feizi, H., and Ahmadian, A. 2016. Effect of planting density on flower and corm yield of Spanish and Iranian saffron (Crocus sativus L.). Saffron Agronomy and Technology, 4(1): 19-27.

Pandy, D., and Srivastava, R.P. 2000. A note on the effect of size of corms on the sprouting and flowering of saffron. Progr. Hortic, 6: 89-92.

Rostami, M., and Mohammadi, H. 2013. Effect of planting date and corm density on growth and yield of saffron in climate of Malayer. Ecology of Agriculture 1:27-38.

Sadeghi B, 1993. Effect of Corm Weight on Saffron Corm Flowering. Publication of Iranian Research Organization for Science and Technology. Center of Khorasan.

Torabi, K., and Sadeghi, B. 1994. Food Changes in Saffron leaf and corm during Growth Season. Papers summaries of Second Conference on Saffron and Pharmaceutical plant cultivation, Gonabad, November 7 and 8.

Yau, S.K., and Nimah, M. 2004. Spacing effects on corm and flower production of saffron. Lebanes Science Journal5:13-20.

\section{How to cite this article:}

Ali, G., M.H. Khan, F.A. Nehvi, S.A. Dar, S.A. Nagoo, S. Naseer, B.A. Alie and Mir G. Hassan. 2018. Study on Yield and Corm Regeneration of Saffron through Different Planting Geometry Patterns. Int.J.Curr.Microbiol.App.Sci. 7(08): 526-534. doi: https://doi.org/10.20546/ijcmas.2018.708.058 